\title{
The Importance of Leadership Function in Non-Profit Sports Organizations
}

\author{
Deni Borozan \\ Aspira College of Management and Design
}

Leading is an integral part and the essence of management, a function that motivates and encourages efforts to achieve the set goals of the organization. The leading function is equally important in non-profits operating in a dynamic global market and fighting for their place under the sun. To be successful and effective, a non-profit organization must coordinate all its available resources, which requires good, quality and specific management. Regardless of the fact that the basic goal of a non-profit organization is a social goal, its activities and business must be guided by application of modern business models by which the non - profit organization will take a competitive position in the non - profit market. The leadership function in non-profits requires skills of focusing on linking social benefits and business practices using successful economic models but neglecting political and individual goals that must not at any time neglect service to society.

Keywords: common good, function of management, non-profit organization, skill, leading

\section{INTRODUCTION}

The intention of this paper is to point out the importance of the leadership function in the management of non-profit sports organizations. Non-profit as a characteristic and specificity means that the basic goal of the organization is not to make a profit but a social goal, social benefit, common good. Consequently, the basic goal of sports non-profit organizations is to achieve a sports mission, sports range and results of importance to the community. As the Croatian Sports Law itself states in Article 1, paragraph 2: "Sports activities are activities of special interest to the Republic of Croatia." However, for success in running a sports non-profit organization, specific knowledge within the field of sports and modern skills are extremely important, ways of doing business certainly satisfying the condition of economic success. To achieve progress and development in all segments of activity, leadership of a modern, non-profit organization needs to skillfully achieve the synergy of several goals - sports results, social performance, socially beneficial changes, economic performance.

\section{DEFINITION OF NON-PROFIT SPORTS ORGANIZATION}

A non-profit sports organization is an organization that operates in the field of sports and whose primary goal is not profit, but a sports result with the highest level of influential and socially useful sports activities. A significant characteristic of a non-profit organization is social responsibility as well as constant activity within the social community with the aim of creating beneficial changes. The surplus income generated in a non-profit organization is not invested in individual, personal capital but is reinvested in sports activities 
with the aim of directing them to a socially beneficial goal. Private entrepreneurship is not inherent in nonprofit sports organizations. However, today's non-profit organizations must be both sports and economically enterprising to survive and develop in the non-profit market and, in addition to social, also achieve economic result and effect. Non-profit sports organizations are funded from budgetary and nonbudgetary funds. It is the social benefit that is expressed through budget funding, through program tenders for public needs in sports through the state budget or the budget of local communities. In this way, the social community strategically supports and stimulates work for the development of the common good as a public need from which society will benefit. Precisely because of this method of financing, the responsibility and transparency of the use of financial resources is very important, as well as the justification of spending according to the registered programs of public importance. By bringing together people of equal interests working for the common good, non-profits express solidarity and the purpose of building a better society. A significant part of sports organizations in the Republic of Croatia operates as sports clubs - non-profit organizations established to perform sports activities prescribed by the Sports Law.

\section{LEADING AS A FUNCTION OF MANAGEMENT WITH BASIC COMPONENTS}

According to Srića (2004), leadership is the ability to influence the behavior of associates and the value system, so that they enthusiastically achieve the goals of the organization. The meaning of leadership is directed towards the process of harmonizing business activities that operate in an atmosphere of inventiveness, creativity, organization, and constant motivation. Leadership encourages action, dedicated and continuously produces high-quality work, creates strong and useful business connections and networks, both internally and externally. Understanding the concept of leadership directs us to understand a very dynamic, intense process in which the characteristics of creativity, motivation, inspiration, constant stimulation plays a significant role. Leadership is a constant process that has the task of motivating, creating, and initiating followers, continually encouraging them to higher achievements and better results, recognizing and releasing the necessary energy, knowledge and skills to achieve goals. Therefore, leadership is a very important function of management and certainly stands out as one of the important functions of management, but it also differs from it. "Determining the difference between a manager and a leader is one of the current topics, because often the two terms are identified, so as an example of the difference in defining a manager and a leader, the attitude that managers deal with things, while leaders deal with people, is the attitude is established. that manager "do things the right way," while leaders "do the right things. (Sikavica, P., Bahtijarević-Šiber, F. 2004) "Leadership can be defined as a set of processes aimed at persuading members of the organization to work on achieving the goals of the organization, and mainly consists of four basic groups of activities: motivation, leadership of interpersonal processes, management groups and conflicts, and communication" (Buble M., 2006). In leadership where the involvement of several people is very easy to conflict, negative but also positive. In addition to emotions such as sadness, anger, hurt and tension, conflict can be seen as a tool of evolution (not revolution) that leads to better solutions, but also to successful coexistence. (Trboglav Podvorac M., 2011). Therefore, the quality of leadership is manifested in the ability of the leader to assertively manage conflicts and lead them in the direction of realizing the vision of his organization. Communication is one of the key components of leadership, because for activities to be carried out, it is necessary to communicate. Given the complexity of communication processes, the role of leadership is to interpret correctly, with understanding, freely and without delay to direct and send important and quality information relevant to the success of the organizational process. It is important for leaders to understand that each communication channel has its advantages and disadvantages and that each can be an effective means of communication in appropriate circumstances (Buble, 2011). Is there a unique leadership model? Certainly not, because as much as there is a leader, there are also leadership models. Individuality creates a separate style marked by different personality traits. Leadership is proactive - problem solving, looking forward, not being satisfied with things as they are. Once their visions are developed, leaders must make them insurmountable and persuasive. An invincible vision is one that people can see, feel, understand, and embrace. Effective leaders provide a rich 
picture of what the future will look like when their visions come true. They tell inspiring stories and explain their visions in a way that everyone can find themselves in them. (Pureta, 2018).

\section{ABOUT LEADERSHIP AND LEADERS}

"Leaders are an inspiration to generations of people. It is therefore no wonder that many try to figure out the characteristics of leaders that their leadership is so successful. (Pureta, 2019). In 1869, Galton concluded in his work "Hereditary Genius" that leadership traits are hereditary and that they are acquired by birth. In his 1904 article "A Preliminary Study in the Psychology and Pedagogy of Leadership," Terman empirically studied leadership. In the conclusions of his research, he states that qualities such as eloquence, intelligence, weak emotional sensitivity, ability to achieve quality relationships with other people, kindness, courage and liveliness, important qualities of young leaders and key to leadership. Based on his research (1959), Mann believes that leaders have the following personality traits: intelligence, masculinity, adaptation, dominance, extroversion, and conservatism. Kirkpatrick and Locke (1991) single out six personality traits according to which leaders differ from persons who are not. These are initiative, desire to lead, honesty and integrity, self-confidence, cognitive abilities, and knowledge of the job. They believe that individuals can be born with some personality traits and learn others." (Pureta, 2019) The conclusion is that a successful leader is one who manages to harmonize and balance all the necessary knowledge, skills, desirable characteristics with each other. focused people leadership techniques. Light (2002) further highlights the most important qualities of a leader in non-profit organizations: honesty, loyalty, determination, trust, and charisma. He adds some more necessary qualities such as profitability, intelligence, social intelligence, communication, and education. Unfortunately, the situation in Croatia greatly emphasizes political affiliation (Marić, 2018)

\section{THE IMPORTANCE OF LEADERSHIP IN NON-PROFIT SPORTS ORGANIZATIONS}

Modern non-profit sports organizations due to global dynamic changes in the overall sports industry must adapt quickly to changes, while maintaining the important role of social responsibility in modern society. A sports organization, regardless of individual goals, represents the public social interest because, by definition, it meets general social criteria and individual human needs, thus producing a strong social effect (Skorić, 2014). The most important thing for any sports organization is to extract its maximum potential from the athlete, and sports management is a set of knowledge and skills that are important for providing many, but especially human resources (athletes) to achieve goals in sports (Tomić, 2007). Sikavica et al. (2008) state that leadership is perhaps the most important function of management, and the same authors emphasize that no function of management determines the success of a company as leadership does. (Sikavica et al., 2008). Smith, Bucklin \& Ass.: "For non-profit organizations, the time for a casual management style based on idealism, not professionalism, is over." According to Drucker (1990), there are three essential dimensions important to the role of a leader in non-profit organizations: the role of the leader must suit you, the role you have taken on must match the task, and the role must meet expectations. Furthermore, Drucker believes that the key competencies of leaders in non-profits are the will, ability, and self-discipline in listening to others; willingness to communicate (be clear in expression) and willingness to prioritize the task over oneself. Modern non-profit sports organizations are organized largely as citizens' associations in which social management is a way of governing. The management structure consists of a team of associated individuals who have common goals, and accordingly, leadership should be focused on achieving common, social goals while increasing the economic value of the organization. What is required of a leader in a non-profit sports organization? Above all, the leader must have a strong vision and awareness of the organization's mission. The mission as the essence and purpose of the organization to the leader must be the starting point in its activities, which means that it must have knowledge about the organization and the environment in which it operates. It is extremely important to recognize and determine the position of the organization in society, its role and to be able to adapt to social changes, but also to lead to socially useful and recognizable changes by acting in the organization. The mission as the essence and purpose of 
the organization to the leader must be the starting point in its activities, which means that it must have knowledge about the organization and the environment in which it operates. It is extremely important to recognize and determine the position of the organization in society, its role and to be able to adapt to social changes, but also to lead to socially useful and recognizable changes by acting in the organization. A leader in a non-profit sports organization should have good organizational skills and abilities to align sports goals and results with the business and be able at any time to take activities and risks desirable for the progress and development of the organization. To achieve all the above, the leader of a non-profit sports organization must be intelligent, adaptable, of exceptional human qualities and professional abilities, possessing specific and broad knowledge, be innovative, creative, agile, constantly lead the organization one step ahead. How is the team run? Pureta (2014) states that Professor of Sociology and Organizational Psychology Dr. J. Richard Hackman from Harvard Kennedy School believed that from the model of a single leader "hero" leadership should be directed towards the model of shared team responsibility they exceed the abilities of the individual regardless of his talent. According to him, the advantages of team leadership are clear goal setting, establishment of coordination procedures and closer supervision so that nothing important is missed. J. Richard Hackman (2004) states that the style of team leaders strongly shapes the behavior of those led: if team members behave cooperatively and competently, leaders tend to act more participatory and democratic, but if team members are uncooperative or seemingly incompetent, leaders tend toward a one-sided, directive style (Farris \& Lim, 1969; Lowin \& Craig, 1968; Sims \& Manz, 1984). Hackman felt that team leadership also creates more flexibility because a team does not depend entirely on just one member. "According to Hackman, joint team leadership can be achieved when certain preconditions are created: the team must be clear who is and who is not a team member, members achieve a common goal depending on each other with the responsibility of the whole team, the team has enough independence in discussing and deciding about its own work processes and is stable enough to learn over time the specific abilities of individual members and how best to cooperate" (Pureta, 2014). It is therefore extremely important that the leader surrounds himself with a team capable of understanding the goal and the work to be done. In this way, it is easier to communicate, implement the vision and mission of the organization, plan, organize, motivate - lead on the way to achieving the goal of the organization. One leader is not able to be always present at all levels. Pureta (2013) believes that an assistant leader should be a leader and that in important places there should be a person who will understand the role of the leader and do the job following a common vision, as well as being able to follow the advice of the leader. In fact, the team must progress and all individuals as part of the team must make sure that their work is done exactly as the leader himself would do it.

The Forbes Non-Profit Council, made up of reputable non-profit leaders, lists seven basic types of leadership that every non-profit organization needs:

1. Individual, organizational and external leadership: development of leadership profiles at all three levels: for individuals, organizational leaders and leaders at the external level as well as the Global Leadership Journey program for middle managers working in all three areas (Elanor Allen, Water for People)

2. Community leadership: focused on the development of the person, the so-called. A hybrid officer who will link the organization's executive strategy with community tactics - Glenn D. Banton, OSD (Supply Drop Organization);

3. Stakeholder and Sponsor Leadership: the presence and support of sponsors is recognized as a catalyst for the greatest achievements... Big brands can confirm great ideas for non-profit organizations- Aaron Alejandro, Texas FFA Foundation.

4. Leadership for problem solving: real leaders are those who encounter problems, challenge the status quo, and unlock the potential of those around them... Casey Enders, Unlocking Potential Foundation.

5. Leadership based on strengths and strengths: instead of focusing on deficits, leadership should focus on highlighting the strengths and strengths of the organization, bragging, and raising morale about your accomplishments - Kimberly Lewis, Goodwill Industries of East Texas, Inc. 
6. Next Generation Leadership: should always listen to the experience, preferences, impressions of younger generations and see what future generations of members want and need - to shape strategic planning and the future of the organization - Peggy Smith, Worldwide ERC.

7. Leadership in Marketing and Communications: every non-profit organization should have a leading communication and marketing expert to direct fundraising campaigns in ways that are relevant to donors, ensuring that messages across all communication channels and locations are strategic, cohesive, and influential. John Lyon, World Hope International. (Forbes Non-Profit Council, 2018).

\section{RESEARCH}

To examine the public opinion about the importance of the role of leadership in non-profit sports organizations, a survey was conducted using the methodology of an online survey questionnaire among sports organizations in the City of Split, in the Republic of Croatia. The survey questionnaire was accessed by a total of 41 respondents, of which 37 respondents or $90.2 \%$ are members of a non-profit sports organization and only 4 respondents $-9.8 \%$ members of a for-profit organization. The survey questionnaire was answered by $36.6 \%-15$ respondents aged 41 to 50 years, $31.7 \%$ - 13 respondents aged 51 years, $22 \%$ aged 31 to 40 years and $9.8 \%$ - 4 aged 20 to 30 years. 24 respondents or $58.5 \%$ of the total of 41 are highly educated, $22 \%$ - 9 of them have a secondary education level and 8 respondents, $19.5 \%$ have a higher education level. Furthermore, the survey showed that out of all respondents, 63.4\%, or 26 are employees and $36.6 \%$, or 15 are volunteers in their organizations. A very high percentage of respondents $61 \%$ (25) identified the president as the initiator of new activities and the leader, an equal number of $14.6 \%$ identified coaches as initiators of activities while the same percentage do not know who initiates the activities, and 4 respondents or $9.8 \%$ believe that it is the secretary who initiates new activities. The person to whom 23 or $56,1 \%$ respondents would turn for a proposal for a solution or as an idea to start a new activity is the president, 9 (22\%) would look for a secretary, 7 (17.1\%) would turn to a coach, and $2(4.9 \%)$ don't know who to turn to at all. Out of a total of 41 respondents, $35(85.4 \%)$ consider leadership to be an extremely important function for the development and success of the organization, while $14.6 \%$ and 6 of them consider it very important. When asked what leadership is, most respondents answered similarly by describing leadership as a function that initiates activities, solves problems, directs, and encourages employees to achieve business goals. They believe that leadership is a combination of responsibility, courage, entrepreneurship, that guide the organization towards achieving the set goal.

\section{CONCLUSION}

Recognizing the fact that the activities and operations of non-profit sports organizations must move away from mere existence and focus on a higher level of quality functioning in modern society, leadership as an integral part of management must be a strategic element of the vision of non-profit sports organization. A non-profit sports organization should lead to a sports goal that will simultaneously have significance and role in society, representing the common good, benefit the community and be economically advanced, competitive, interesting and bring significant changes in the development and progress of themselves and the social environment in which they operate. Leadership determines the direction of an organization's development, whether it will be successful or fail. A leader is unquestionably a person who must possess exceptional knowledge, communication skills, have the charisma of a leader that followers will follow to achieve the goal of the organization - to follow the leader, to address and seek impulse inspiration and motivation from the same and the leader to lead followers exemplary following the forces of environment and resisting challenges. "Being first among equals", being strong, brave, adaptable, encouraging, developing an entrepreneurial and winning atmosphere, recognizing, and knowing opportunities, increasing and developing strengths, reducing threats, pulling forward, opening new paths and developing relationships, leading a sports organization as needed and market demands within global trends, create socially beneficial changes. Because as Ronald Reagan, one of the American presidents, said: "The greatest 
leader is not necessarily the one who does the greatest things. He is the one that gets the people to do the greatest things".

\section{REFERENCES}

Buble, M. (2011). Poslovno vođenje. Zagreb: M.E.P.

Buble. M. (2006). Menadžment. Ekonomski fakultet u Splitu, Split.

Drucker, P. (1990). Managing the Non Profit Organization. Butterworth-Heineman, Oxford.

Forbes Nonprofit Council. (2018). Seven Essential Types of Leadership Every Nonprofit Organization Needs. Retrieved from https://www.forbes.com/sites/forbesnonprofitcouncil/2018/09/14/sevenessential-types-of-leadership-every-nonprofit-organization-needs/?sh=7aa3e7961d21

Hackman J.R. (2004). What makes for a great team? American Psychological Association. Retrieved from https://www.apa.org/science/about/psa/2004/06/hackman

Marić, I. (2018). Menadžment neprofitnih organizacija. Sveučilište u Zagrebu Ekonomski fakultet

Partus Akademija. (n.d.). Retrieved from https://partus-akademija.com/svaki-uspjesan-tim-imauspjesnog-vodu/

Pureta, I. (2018). Vodstvo stvara viziju budućnosti. RAMIRO. Retrieved from https://www.ramiro.hr/baza-znanja/vodstvo-stvara-viziju-buducnosti)

Pureta, I. (2013). Lider treba lidere. RAMIRO. Retrieved from https://www.ramiro.hr/baza-znanja/lidertreba-lidere

Pureta, I. (2014). Poduzeće se treba okrenuti timskom leadership. RAMIRO. Retrieved from https://www.ramiro.hr/baza-znanja/poduzece-se-treba-okrenuti-timskom-leadershipu

Pureta, I. (2019). Vođenje temeljeno na crtama ličnosti voditelja. RAMIRO. Retrieved from https://www.ramiro.hr/baza-znanja/vodenje-temeljeno-na-crtama-licnosti-voditelja

Sikavica, P., Bahtijarević-Šiber F., \& Poloski Vokić, N. (2008). Temelji menadžmenta. Školska knjiga, Zagreb.

Sikavica, P., \& Bahtijarević-Šiber, F. (2004). Menadžment - teorija menadžmenta i veliko empirijsko istraživanje u Hrvatskoj. Masmedia, Zagreb.

Srića, V. (2004). Biblija modernog vođe. Znanje, Zagreb.

Tomić, M. (2007). Sportski menadžment. Beograd.

Trboglav Podvorac, M. (2011). Pretvorite konflikt u pobjedu! Retrieved from https://www.ramiro.hr/bazaznanja/pretvorite-konflikt-u-pobjedu

ZAKON.HR. (n.d.). Zakon o sportu. Retrieved from https://www.zakon.hr/z/300/Zakon-o-sportu 